\title{
LEGAL REGULATION OF THE FIGHT AGAINST AND PREVENTION OF TAX EVASION BY WAYS OF LEGISLATIVE DELEGATION. CONSTITUTIONAL LIMITS
}

\author{
A. M. Popescu, I. Cochințu
}

\author{
Agata Mihaela Popescu \\ Facutly of Juridical and Administrative Sciences \\ "Dimitrie Cantemir" Christian University, Bucharest, Romania \\ * Correspondence: Agata Mihaela Popescu, 129 Şoseaua Olteniei St., Sector 4, Bucharest, \\ Romania \\ E-mail: av.agata@yahoo.com
}

\section{Ioniţa Cochinţu}

Assistant Magistrate at the Constitutional Court of Romania, $\mathrm{PhD}$ Candidate at the West University of Timisoara,

Faculty of Law, Timişoara, Romania

\section{Abstract}

Citizens have an obligation to contribute, through taxes and fees, to public expenditure, as regulated by law, but there are situations where payers of fees, taxes or other contributions avoid paying them, which leads to tax evasion'.

Over time, the lawmaker was concerned with adopting rules meant to establish specific measures for fighting against and preventing tax evasion, especially in the context of Romania's integration in the European Union. In the present wok, in addition to presenting the implementation at infraconstitutional level of the rules of the Basic Law and the legislative dynamics of the rules that have governed this area, we are trying to answer the natural question of whether the criminalization of tax evasion acts can be achieved by way of legislative delegation, namely by simple or emergency ordinances of the Government or it can only be done by "law" as an act of Parliament.

Keywords: tax evasion, legislative delegation, taxes and fees, state budget, constitutional review, law.

\section{Introduction}

\section{Introductory and Legislative Issues}

Romania's economy is a market economy ${ }^{2}$, based on free enterprise and competition, the need for the state to ensure the protection of fair competition, the establishment of a favourable framework for putting to use all factors of production, as well as the protection of national interests in the economic, financial and currency activity. Also, citizens have an obligation to contribute, through taxes ${ }^{3}$ and fees, to public expenditure ${ }^{4}$.

\footnotetext{
${ }^{1}$ According to Article 1 of Law No. 87 of 18th October 1994 on tax evasion, published in the Official Journal of Romania, Part I, no. 299 of 24th October, "Tax evasion is the avoidance by any means, in whole or in part, of payment of taxes, fees and other amounts owed to the state budget, local budgets, the state social insurance budget and special extra-budgetary funds by Romanian or foreign natural persons and legal entities, hereinafter called taxpayers".

2 As stated in the Romanian Constitution in Article 135 - "Economy".

${ }^{3}$ Ţîrlea M. R., Fiscalitate, Manual de studiu individual (Taxation, A Self-Study Handbook), p.5.

${ }^{4}$ According to Article 56 of the Romanian Constitution.
} 
Depending on the evolution of society, the needs and opportunities of social and economic reality, laws are modified, supplemented or undergo various legislative events, this being also the case of materials governing the fight against and prevention of tax evasion, a field on which particular emphasis is placed, the lawmaker being constantly concerned with adopting measures conducive to the prevention and limitation of the tax evasion phenomenon.

Thus, over time, after the adoption of the Constitution in 1991, the lawmaker implemented the constitutional provisions by adopting a series of regulatory acts that laid the foundation for a tax system and established a number of tax principles, while, of course, taking into account the Community rules in the matter.

In this sense, for example, the Accounting Law No.82/1991 ${ }^{5}$ was adopted, also the Government Ordinance No.17/1993 establishing and sanctioning contraventions of financial management and tax regulations and one of the first regulatory acts ${ }^{6}$, Government Ordinance No. 26/1993 regarding Romania's customs import tariff, Law No. 87/1994 on fighting tax evasion, Government Ordinance No. 70/1994 on the income tax ${ }^{8}$, Law No.141/1997 - the Romanian Customs Code ${ }^{9}$, subsequently repealed in 2001, a new Customs Code being adopted, the Tax Code ${ }^{10}$ or Law No. 241/2005 on preventing and fighting tax evasion. A particular regulatory act is Government Emergency Ordinance No. 54/2010 on measures aimed at fighting tax evasion ${ }^{11}$, which will be a special subject of our analysis.

\section{Criminalization of Tax Evasion Acts and Legislative Delegation}

Given the need to strengthen the legal framework of the antifraud fight in order to protect the EU's financial interests, to control the implementation of internationally-funded programmes and the implementation of the acquis communautaire, the Antifraud Fight Department was established, as a contact institution with the European Antifraud Fight Office $^{12}$, with the main task of ensuring the coordination of the antifraud fight and an effective and equivalent protection of the European Union's financial interests in Romania. Also, the National Agency for Tax Administration was established, which in 2013 was reorganized ${ }^{13}$ as a result of the merger by absorption and takeover of the activity of the Customs National Authority and by takeover of the Financial Guard's activity.

From the analysis of the laws set forth above, it is inferred that, in general, the regulation of taxation measures or measures for fighting and preventing tax evasion, as well as tax fraud were carried out both by law, as an Act of Parliament, and by Government ordinances or emergency ordinances.

Certain regulatory acts, such as Law No. 241/2005 on preventing and fighting tax evasion, the Customs Code, the Tax Code or Government Emergency Ordinance No. 54/2010 on measures aimed at fighting tax evasion, punish certain tax evasion acts, stating that they are contraventions or offences.

The natural question arising and which we are trying to answer is whether the criminalization of tax evasion acts can be achieved by way of legislative delegation, namely by simple or emergency ordinances of the Government or it can only be done by "law" as an

\footnotetext{
${ }^{5}$ Published in the Official Journal of Romania, Part I, No. 265 of 27th December 1991.

${ }^{6}$ Published in the Official Journal of Romania, Part I, No. 205 of 25th August 1993.

${ }^{7}$ Published in the Official Journal of Romania, Part I, No. 213 of 31st August 1993.

${ }^{8}$ Published in the Official Journal of Romania, Part I, No. 246 of 31st August 1994.

${ }^{9}$ Published in the Official Journal of Romania, Part I, No. 180 of 1st August 1997.

${ }^{10}$ Law No. 571/2003, published in the Official Journal of Romania, Part I, No. 927 of 23rd December 2003.

${ }^{11}$ Published in the Official Journal of Romania, Part I, No. 421 of 23rd June 2010.

12 The Antifraud Fight Department was established by Government Emergency Ordinance No. 49/2005 on the setting of some reorganization measures within the central public administration, published in the Official Journal of Romania, Part I, No. 517 of 17 th June 2005.

${ }^{13}$ Reorganized by Government Emergency Ordinance No. 74/2013 on measures to improve and reorganize the activity of the National Agency for Tax Administration and amending and supplementing certain regulatory acts, published in the Official Journal of Romania, Part I, No. 389 of 29th June 2013.
} 
act of Parliament and to what extent, as regards the Customs Code or of Law No. 241/2004 on preventing and fighting tax evasion, as organic laws, may they be amended or supplemented by emergency ordinances as "administrative acts in the field of law".

Starting from the constitutional provisions of Article 73 - Categories of Laws, corroborated with those of Article 115 - Legislative Delegation, certain specifications are required: according to Article 73 para. (1) of the Constitution, "Parliament passes constitutional, organic and ordinary laws" and according to para. (3) point h), "The organic law shall regulate: [... ] offences, penalties and the execution thereof', at the same time, it is worth mentioning that, by way of legislative delegation, under Article 115 para. (4)-(6), the Government may adopt emergency ordinances and in the field of organic laws. To answer this question, we should start with the constitutional provisions which enshrine the possibility for Parliament to delegate its legislative task, as established by Article 61 para. (1) of the Constitution, endowed with the value of a principle, which states that it is "the sole legislative authority of the country", to the Government, provisions contained in Article 115 on legislative delegation. Under these constitutional provisions, there may be two types of legislative delegation, legislative delegation being an institution specific of constitutional law ${ }^{14}$, namely a constitutional legislative delegation and a legal legislative delegation ${ }^{15}$.

Therefore, legislative delegation may be given directly by the constitution or by a special law, without requiring prior authorization by a public authority ${ }^{16}$.

Legal legislative delegation occurs under a law enabling the Government to issue ordinances. Thus, Parliament may pass a special law enabling the Government to issue ordinances in areas not subject to organic laws, under certain conditions, of course ${ }^{17}$.

Constitutional legislative delegation operates directly under the provisions of the Constitution, but it must also meet certain conditions ${ }^{18}$.

\footnotetext{
${ }^{14} \mathrm{See}$, in this respect, I. Vida, Legistică formală, Introducere în tehnica şi procedura legislativă, Bucureşti, 2010, p. 242. (Formal Laws. Introduction to Legislative Technique and Procedure, Bucharest, 2010, p. 242).

${ }^{15}$ Idem. It is considered that "legislative delegation means the transfer of legislative tasks from Parliament to the Government under certain conditions established by the Constitution, the law or even the taking over of certain tasks by the executive power, by virtue of certain states of fact".

${ }^{16}$ L. Dragne, A. Pascu, Delegarea legislativă, Analele Universităţii Creştine Dimitrie Cantemir”, Seria Drept, Anul XIII (2), no.2/2009, Ed. Pro Universitaria, Bucureşti, 2009, p. 43 (Legislative Delegation, Annals of the "Dimitrie Cantemir" Christian University, Law Series, Year XIII (2), No. 2/2009, Pro Universitaria Publishing House, Bucharest, 2009, p 43).

${ }^{17}$ Article 115 para. (1)-(3) of the Romanian Constitution: “(1) Parliament may pass a special law enabling the Government to issue ordinances in fields outside the scope of organic laws. (2) The enabling law shall compulsorily establish the field and the date up to which ordinances may be issued. (3) If the enabling law so requests, ordinances shall be submitted to Parliament for approval, according to the legislative procedure, until the expiry of the enabling time limit. Non-compliance with the term entails discontinuation of the effects of the ordinance".

18 Article 115 para. (4)-(8) of the Romanian Constitution: “(4) The Government can only adopt emergency ordinances in extraordinary situations, the regulation of which cannot be postponed, and have the obligation to give the reasons for the emergency status within their contents.

(5) An emergency ordinance shall only come into force after it has been submitted for debate in an emergency procedure to the Chamber having the competence to be notified, and after it has been published in the Official Journal of Romania. If not in session, the Chambers shall be convened by all means within 5 days after submittal, or, as the case may be, after forwarding. If, within 30 days at the latest of the submitting date, the notified Chamber does not pronounce on the ordinance, the latter shall be deemed adopted and shall be sent to the other Chamber, which shall also make a decision in an emergency procedure. An emergency ordinance containing norms of the same kind as the organic law must be approved by a majority stipulated under article 76 (1).

(6) Emergency ordinances cannot be adopted in the field of constitutional laws, or affect the status of fundamental institutions of the State, the rights, freedoms and duties stipulated in the Constitution, the electoral rights, and cannot establish steps for transferring assets to public property forcibly.

(7) The ordinances the Parliament has been notified about shall be approved or rejected in a law which must also contain the ordinance that ceased to be effective according to paragraph (3).
} 
According to the Basic Law, the Government may adopt emergency ordinances only in extraordinary situations the regulation of which cannot be postponed, and have the obligation to justify the emergency in their contents, but emergency ordinances may not be adopted in the field of constitutional laws, they may not affect the status of the fundamental state institutions, the rights, freedoms and duties enshrined in the Constitution, electoral rights and may not establish measures of forcible transfer of assets to public ownership.

Therefore, according to the constitutional provisions already mentioned, the Government may adopt an emergency ordinance under the following conditions: the existence of an extraordinary situation; its regulation cannot be posponed; the emergency should be motivated in the content of the ordinance; it should not be adopted in the field of constitutional laws; it should not affect the status of the fundamental state institutions; it should not affect the rights, freedoms and duties enshrined in the Constitution, nor electoral rights; it cannot establish measures of forcible transfer of assets to public ownership ${ }^{19}$.

As regards their adoption "only in extraordinary situations the regulation of which cannot be posponed, with the obligation to justify the emergency in their contents", it is necessary for these three conditions to be met cumulatively.

Moreover, after the constitutional revision of 2003, the term "exceptional cases" as used in the Constitution adopted in 1991 has been replaced by that of "extraordinary situations $" 20$.

However, as noted in the jurisprudence, "beyond the categorical nature of the wording used by the Constitution lawmaker, its intent and the purpose pursued consisted in restricting the scope within which the Government may replace Parliament, adopting primary rules in consideration of reasons that it is sovereign to determine by itself ${ }^{121}$.

Given the fact that the Basic Law does not specify the content of the concept of "exceptional cases" or "extraordinary situations", it fell upon the Constitutional Court to develop the meaning of these two phrases. Thus, starting from a systematic interpretation, both within the logic of the legislative delegation institution [enshrined by Article 114] and of the constitutional edifice as a whole, it showed that "exceptional cases ${ }^{22}$, within the meaning of Article 114 para. (4) of the Constitution, are those situations that do not fall within those expressly envisaged by the law. Consequently, if the lawmaker did not set a norm specific of an exceptional circumstance, it would be contrary to its very will if the existing rules were applied to the exceptional cases referred to by Article 114 para. 4 of the Constitution. Given this, the public interest adversely affected by the abnormal and excessive nature of exceptional cases justifies Government intervention by way of the emergency ordinance" and the existence of the exceptional case "does not depend on the will of the Government which, in such circumstances, is forced to react promptly in order to defend a public interest by way of the emergency ordinance, ${ }^{, 23}$.

\footnotetext{
(8) The law approving or rejecting an ordinance shall regulate, if such is the case, the necessary measures concerning the legal effects caused while the ordinance was in force".

${ }_{19}$ These conditions are set out in the constitutional provisions of Aarticle 115 par. (4)-(6) of the Romanian Constitution.

${ }^{20} \mathrm{Idem}$, it is shown that "although the difference between the two terms, in terms of the degree of deviation from the ordinary or common which they express is evident, the same lawmaker felt the need to prevent any interpretation that might minimize such a difference, by adding the phrase "the regulation of which cannot be postponed", thus consecrating in terminis the imperative of the emergency of the regulation".

${ }_{21}$ Decision No. 255 of 11 th May 2005, published in the Official Journal of Romania, Part I, no. 511 of 16th June 2005.

${ }_{22}$ Decision No. 65 of 20th June 1995, published in the Official Journal of Romania, Part I, no. 129 of 28th June 1995.

${ }^{23}$ Decision No. 83 of 19th May 1998, published in the Official Journal of Romania, Part I, no. 211 of 8th June 1998.
} 
Therefore, such a "measure can only be grounded on the necessity and urgency to regulate a situation which, because of its exceptional circumstances, calls for immediate solutions, in order to avoid serious harm to the public interest ${ }^{, 24}$.

Of course, these interpretations were completed by the wording "the regulation of which cannot be postponed", thus consecrating in terminis the imperative of the emergency of the regulation and, for reasons of legislative rigour, imposed the requirement of motivating the emergency within the very content of the ordinance adopted outside an enabling law ${ }^{25}$.

Also, regarding the "exceptional case" and "emergency", it was stated that "emergency regulation is not equivalent to the existence of extraordinary circumstances".

Regarding the concept of "law" used throughout the constitutional provisions, this concept was used in the Constitution, "in its broadest sense, which includes the Constitution, as the Basic Law, and all other regulatory acts, with a legal force equivalent to the law or inferior to $i t^{27}$, having several ${ }^{28}$ meanings "depending on the distinction operating between the formal or organic criterion and the material one, and the law is characterized as an act of the legislative authority, being identified according to the body required to adopt it and the procedure to be followed for this purpose".

As regards Government ordinances, it was retained both in the doctrine ${ }^{29}$ and in the jurisprudence that, by developing such regulatory acts, the administrative body exercises a granted competence which, by its nature, falls within the legislative competence of Parliament. Therefore, the ordinance is not a law in the formal sense, but an administrative act in the field of law, assimilated by the effects it produces to the law, compliant, in this respect, with the material criterion ${ }^{30}$.

Hence, given the fact that a regulatory legal act is generally defined both by its form and its content, the law, in a broad sense, is the result of combining the formal criterion with the material one ${ }^{31}$, including assimilated regulations, too.

We see, then, that the emergency ordinance may also regulate matters of organic laws and the matter referred to in Article 73 para. (3) point $h$ ) regarding offences, penalties and the execution thereof. But to what extent are the constitutional requirements of Article 115 para. (6) regarding the effect on the constitutional status of the rights and freedoms provided for by the Constitution, as well as those regarding the fact that "the law only provides for the future", respected? We have in view, on the one hand, the fact that the sanction of deprivation of freedom restricts a fundamental right, namely individual freedom provided for as such in Article 23 of the Constitution, being found among the fundamental rights enshrined in the

\footnotetext{
${ }^{24}$ Decision No. 65 of 20th June 1995, published in the Official Journal of Romania, Part I, no. 129 of 28 th June 1995.

${ }^{25}$ Idem, Decision No. 255 of 11 th May 2005.

${ }^{26}$ Decision No. 421 of 9th May 2007, published in the Official Journal of Romania, Part I, no. 367 of 30 th May 2007.

${ }^{27}$ See, in this respect, Decision No. 799 of 17 th June 2011 on the draft law on the revision of the Constitution of Romania, published in the Official Journal of Romania, Part I, No. 440 of 23rd June 2011.

${ }^{28}$ Decision No.120 of 16th March 2004, published in the Official Journal of Romania, Part I, no. 296 of 5 th April 2004. "This conclusion results from the corroboration of Article 61 para. (1) second thesis of the Constitution, republished, under which 'Parliament is [... ] the sole legislative authority of the country' with the provisions of Article 76, Article 77 and Article 78, according to which the law passed by Parliament is subject to promulgation by the President of Romania and shall enter into force three days after its publication in the Official Journal of Romania, unless a later date is provided for in its content. The material criterion has in view the content of the regulation, being defined in considering the object of the rule, respectively the nature of the social relations regulated'.

${ }^{29}$ Ioan Vida, op. cit.

${ }^{30}$ See, in this respect, Decision No. 799 of 17 th June 2011 on the draft law on the revision of the Constitution of Romania, published in the Official Journal of Romania, Part I, No. 440 of 23rd June 2011.

${ }^{31}$ Decision No. 120 of 16th March 2004, published in the Official Journal of Romania, Part I, no. 269 of 5 th April 2004.
} 
Romanian Constitution, in Title II - Fundamental rights, freedoms and duties, or the inviolability of the domicile.

On the other hand, it is worth noting that, according to Article 115 para. (5) of the Constitution, "An emergency ordinance shall only come into force after it has been submitted for debate in an emergency procedure to the Chamber having the competence to be notified, and after it has been published in the Official Journal of Romania. If not in session, the Chambers shall be convened by all means within 5 days after submittal, or, as the case may be, after forwarding. If, within 30 days at the latest of the submitting date, the notified Chamber does not pronounce on the ordinance, the latter shall be deemed adopted and shall be sent to the other Chamber, which shall also make a decision in an emergency procedure. An emergency ordinance containing norms of the same kind as the organic law must be approved by a majority stipulated under article 76 (1)".

From the analysis of this constitutional text it results that, in order to enter into force and produce legal effects, an emergency ordinance must meet two conditions:

1. to be submitted, for debate in an emergency procedure, to the Chamber having the competence to be notified;

2. to be published in the Official Journal of Romania..

Thus, it can be seen that the provisions of Article 115 para. (5) of the Constitution establish an exemption from the entry into force of the law laid down in Article 78 of the Constitution, which operates as a result of the conditions that require the use of enactment by adopting emergency ordinances.

In terms of the time limits for the entry into force of emergency ordinances ${ }^{32}$, apparently, there are two of them. The first one concerns the submitting of the ordinance for debate in an emergency procedure to the competent Chamber, and the second, the publication in the Official Journal. It is only an appearance, because it is inconceivable that the ordinance could be published in the Official Journal before submitting the law for approval to the competent Chamber.

From the wording of Article 115 para. (5), and by corroborating it with the provisions of Article 107 para. (4) and the principle nemo censetur legem ignorare (nobody is thought to be ignorant of the law), the idea that these ordinances cannot enter into force before being published in the Official Journal emerges ${ }^{33}$.

Moreover, both in the doctrine ${ }^{34}$ and in the jurisprudence, it is considered that the entry into force of emergency ordinances takes place on the day of their publication in the Official Journal of Romania, under the conditions specified above, or on a date set within the content of the regulatory act. This is also stated by Law no.24/2000 on rules of legislative technique for drafting regulatory acts ${ }^{35}$, namely in Article $12^{36}$ - Entry into force of regulatory acts.

\footnotetext{
32 I. Muraru, E.S. Tănăsescu (coord.), Constituţia României, Comentariu pe articole, Editura C.H. Beck, Bucureşti, 2008 (The Romanian Constitution, Comments by Articles, Publishing House C.H. Beck, Bucharest, 2008).

${ }^{33}$ I. Vida, Legistică formală, Introducere în tehnica şi procedura legislativă, Editura Lumina Lex, Bucureşti, 2010 (Formal Laws. Introduction to Legislative Technique and Procedure, Lumina Lex Publishing House, Bucharest, 2010).

${ }^{34}$ See also L. Dragne, Drept constituţional şi instituţii politice, vol. II, Ediţia a II-a revăzută şi adăugită, Editura Universul Juridic, Bucureşti, 2012, pp. 115-116 (Constitutional Law and Political Institutions, Volume II, Second edition revised and enlarged, Legal Publishing House, Bucharest, 2012, pp. 115-116).

${ }^{35}$ Republished in the Official Journal of Romania, Part I, no. 260 of 21 st April 2010.

${ }^{36}$ Article 12 of Law no. 24/2000: "(1) The laws and ordinances issued by the Government based on a special law authorising it to do so shall come into effect 3 days after the date of their publication in the Official Journal of Romania, Part I, or on a subsequent date stipulated in their texts. The 3-day delay shall be calculated based on calendar days, starting on the date of their publication in the Official Journal of Romania, and shall expire at 24:00 hours on the third day from their publication.

(2) Emergency Government ordinances shall come into effect on the date of their publication in the Official Journal of Romania, Part I, provided they have been previously submitted to the competent Parliament Chamber to be notified, if no subsequent date is stipulated in their contents.
} 


\section{Conclusions}

An important moment in the legislative dynamics on fighting and preventing tax evasion was the adoption of Government Emergency Ordinance no. 54/2010 on measures aimed at fighting tax evasion ${ }^{37}$.

First, by this regulatory act other deeds were assimilated to the offences of smuggling, namely $^{38}$ “.... the collection, possession, production, transportation, taking over, storage, delivery, marketing and sale of goods or merchandise that must be placed under a customs procedure knowing that they come from smuggling or are intended to committing it, are assimilated to the offence of smuggling" and are punishable by imprisonment of 2-7 years and interdiction of certain rights ${ }^{39}$, being thus criminalized acts that had not previously fallen within the criminal illicit sphere. Secondly, the amount of the penalties established by the Tax Code was increased ${ }^{40}$.

Also, the date of entry into force is expressly mentioned in its content, by practically taking over the constitutional provisions, namely "the provisions of this emergency ordinance for the entry into force of which no time limit has been expressly stipulated, shall apply from the date of publication in the Official Journal of Romania, Part I,41, provisions which were the subject of unconstitutionality, the motivation being that the ordinance came into force on the day of its publication in the Official Journal of Romania, although it is stated that it enters into force "after" publication, which does not correspond to the day of publication. In answer to this criticism, the contentious constitutional court showed ${ }^{42}$ that "the provisions of Article 115 para. (5) of the Constitution are an application of Article 15 para. (2) of the Basic Law, which states that the law only provides for the future, with the exception of the more favourable criminal law or contraventional law, in relation to the entry into force of emergency ordinances if they criminalize a socially dangerous act, regulate the constitutive content of the offence by incorporating new, additional elements to the original rule or their sanctioning regime in order to increase the special minimum or maximum".

(3) The regulatory acts stipulated under article 11 (1), except for laws and ordinances, shall come into effect on the date of their publication in the Official Journal of Romania, Part I, if no subsequent date is date is stipulated in their contents. When it is not necessary that they should come into effect on the date of their publication, such regulatory acts shall state in their contents that they come into effect on a subsequent date set out in the text".

${ }^{37}$ Published in the Official Journal of Romania, Part I, no. 421 of 23rd June 2010.

${ }^{38}$ According to Article IX section 2 of Government Emergency Ordinance no. 54/2010.

39 As set out in Article 270 para. (1) of the Customs Code. Also, new offences were introduced in the Tax Code, namely those referred to in Article 2961 para. (1) points $\mathrm{m}$ ) and 1), and the punishment for which is imprisonment, which is, from the criminalization of the acts, from one to four years. These new offences were introduced by Article I section 23. "In Article 2961 para (1), after point k ), two new points are introduced, points 1) and $\mathrm{m}$ ), with the following content:

"l) the possession by any person outside a fiscal warehouse or marketing on the Romanian territory of excisable products subject to marking, according to Title VII, without being marked or improperly marked or with false markings above the limit of 10,000 cigarettes, 400 cigars of 3 grams, 200 cigars of more than 3 grams, over $1 \mathrm{~kg}$ of smoking tobacco, more than 200 liters of spirits, more than 300 liters of alcohol intermediates;

$m$ ) the use of mobile pipes, flexible hoses or other similar pipes, the use of uncalibrated tanks, and the placement of valves or taps before the meter by means of which alcohol or distilled unmetered amounts can be extracted".

${ }^{40}$ Thus, by Government Emergency Ordinance no. 54/2010, Article 2961 para. (2), point a) of the Tax Code was modified, namely the special maximum penalty for the offences referred to in Article 2961 para. (1) points c), d), e), g), i) in the Tax Code increased 3 to 4 years.

${ }^{41}$ This legal text was subject to constitutional review, the motivation being that the ordinance came into force on the day of its publication in the Official Journal of Romania, although it is stated that it enters into force "after" publication, which does not correspond to the day of publication. The orders challenged in the respective case establish that the provisions of the Government Emergency Ordinance no. 54/2010 on measures aimed at combating tax evasion shall apply from the date of publication in the Official Journal of Romania, Part I, the fact that only after publication may we speak of entry into force being obvious enough. As regards the entry into force of regulatory acts, this makes up the subject of another study.

${ }^{42}$ In this respect, see Decision No. 28 of 5th February 2013, published in the Official Journal of Romania, Part I, no. 164 of 27 th March 2013. 
In the context presented, both the phrase contained in Government Emergency Ordinance no. 54/2010 and that in the Constitution have the same legal effects, being an application of the principle of non-retroactivity of the law, except for the more favourable criminal or contraventional law. Furthermore, by corroborating constitutional provisions, the idea that emergency ordinances cannot enter into force before being published in the Official Journal emerges, the date of publication being relevant to the date of entry into force of the regulatory act.

But the contencious constitutional court shows that "the situation is different as concerns the date of application of the regulatory act which, according to the principle of mitior lex (milder law) is within the competence of the judicial authority", therefore, it falls upon the court to interpret and apply the law in the course of time.

So, from the examination of the constitutional provisions it results that for the emergency ordinance to enter into force, hence to produce legal effects, it must meet certain conditions, namely it must be submitted to the Chamber having the competence to be notified in order to be debated in an emergency procedure, and be published in the Official Journal of Romania. If the Senate and the Chamber of Deputies are not in session, they shall be convened mandatorily within 5 days from the submitting or, where appropriate, from the forwarding.

As we see, the submittal of the emergency ordinance to the Chamber having the competence to be notified and its publication are two successive stages in the regulatory process. As regards the entry into force "on the date of its publication in the Official Journal" and "after its publication in the Official Journal" (constitutional text), both phrases express mathematically the same thing: the emergency ordinance shall enter into force on the day when it is published.

As stated in the Official Journal, the publication date for Government Emergency Ordinance no. 54/2010 is 23 rd June 2010. This is the day of both its entry into force and the beginning of its application. The date of the publication of the ordinance is the zero hour of that day. Only after this date/time can ordinances be applied. So, the date of entry into force of the Ordinance and "from the date of publication" have the same meaning. Thus, it can happen for a person to be held criminally liable for an act he/she has committed just before the unfolding of the procedures provided for by Article 115 para. (5), if the day of entry into force corresponds to the day of publication in the Official Journal or, why not, even to the day of adoption by the Government.

Given the above, although it is considered that the delegated lawmaker is not bound to legislate in the field of organic law, respectively that of offences or penalties, we believe, however, that an analysis is required concerning the constitutional provisions on the prohibition of regulation by way of legislative delegation provided for in Article 115 para. (6) in relation to the fact that emergency ordinances cannot affect fundamental rights and freedoms, and follow the constitutional regime of the entry into force of the law laid down in Article 78 of the Constitution, namely, "the law shall enter into force 3 days after the date of its publication in the Official Journal of Romania, Part I, or on a subsequent date stipulated in its text", which would be consistent with both the constitutional provisions and the conventional ones regarding the predictability of the law, this being also the intention inthe jurisprundece of the European Court of Human Rights, which ruled that the legal rule must be accessible and foreseeable enough for citizens to have sufficient information on the legal rules applicable in a given case and thus, be able to foresse, to a reasonable extent, the consequences that may $\operatorname{arise}^{43}$.

\footnotetext{
${ }^{43}$ This is the intention of the Decision of 25 th November 1996, in the Case Wingrove v. United Kingdom, by which the European Court of Human Rights held that a relevant domestic law, encompassing both written law and unwritten law, must be phrased with enough precision to allow those concerned, who may resort, if necessary, to an expert's advice, to foresee, to a reasonable extent, in the particular circumstances of the case, the consequences that may result from a determined act.
} 


\section{Bibliography}

Țîrlea M. R., Fiscalitate, Manual de studiu individual, (Taxation, A Self-Study Handbook), Pro Universitaria Publishing House, 2012;

L. Dragne, Drept constituţional şi instituţii politice, (Constitutional Law and Political Institutions), Volume II, Second edition revised and enlarged vol. II, Legal Publishing House, Bucharest, 2012;

I. Vida, Legistică formală, Introducere în tehnica şi procedura legislativă (Formal Laws. Introduction to Legislative Technique and Procedure), "Lumina Lex" Publishing House, Bucharest, 2010;

L. Dragne, A. Pascu, Delegarea legislativă, in "Analele Universităţii Creştine "Dimitrie Cantemir", Annals of the "Dimitrie Cantemir" Christian University, Law Series, Year XIII (2), No. 2/2009, Pro Universitaria Publishing House, Bucharest, 2009;

I. Muraru, E.S. Tănăsescu and others, Constituţia României, Comentariu pe articole, (The Romanian Constitution, Comments by Articles), C.H. Beck Publishing House, Bucharest, 2008. 